\title{
INISIASI TUNAS KOKOLECERAN (Vatica bantamensis) PADA BERBAGAI JENIS MEDIA TANAM DAN KONSENTRASI BAP (BENZYL AMINO PURINE) SECARA IN VITRO
}

\section{BUD INITIATION OF KOKOLECERAN (Vatica bantamensis) ON VARIOUS MEDIA AND CONCENTRATIONS OF BAP (Benzyl Amino Purine) IN IN VITRO}

\author{
Sri Sudiyanti, Tubagus Bahtiar Rusbana, Susiyanti \\ Jurusan Agroteknologi Fakultas Pertanian Universitas Sultan Ageng Tirtayasa \\ Jalan Raya Jakarta Km. 4 Serang-Banten \\ Korespondensi : susiyanti@untirta.ac.id
}

Diterima 16 Desember 2016 / Disetujui 29 Juli 2017

\begin{abstract}
ABSTRAK
Kokoleceran (Vatica bantamensis) merupakan tanaman endemik Banten yang hanya ada di Ujung Kulon, dan telah ditetapkan sebagai tanaman identitas Provinsi Banten. Saat ini Kokoleceran terancam punah. Berdasarkan data dari IUCN sejak tahun 1998 tidak ada lagi penelitian mengenai tanaman ini. Inisiasi Kokoleceran memerlukan teknologi untuk mencegah dari kepunahan. Salah satu perbanyakan massal bisa melalui teknik in vitro kultur jaringan. Penelitian dilaksanakan dari November 2015 sampai Maret 2016 di Laboratorium Bioteknologi Jurusan Agroekoteknologi, Fakultas Pertanian, Universitas Sultan Ageng Tirtayasa, Serang, Banten. Penelitian ini menggunakan Rancangan Acak Lengkap faktorial. Faktor pertama yaitu media yang terdiri dari MS dan WPM. Faktor kedua yaitu konsentrasi BAP yang terdiri dari empat taraf, yaitu : $0 \mathrm{mg} \mathrm{L}^{-1}, 1 \mathrm{mgL}^{-1}, 2 \mathrm{mg} \mathrm{L}^{-1}$, dan $3 \mathrm{mg} \mathrm{L}^{-1}$. Hasil menunjukkan bahwa penggunaan media yang berbeda dan konsentrasi BAP tidak berpengaruh pada waktu kemunculan tunas, jumlah tunas, dan jumlah. Namun, kedua perlakuan berpengaruh terhadap warna media dan pertumbuhan kalus pada eksplan.
\end{abstract}

Kata kunci : BAP, endemis, in vitro, kokoleceran (Vatica bantamensis), media

\begin{abstract}
Kokoleceran (Vatica bantamensis) is an endemic plant of Banten which is only in Ujung Kulon, and has been designated as identity of Banten province. Now the existence of Kokoleceran has been endangered. Based on data from the IUCN, since 1998 there has been no research. Kokoleceran initiation needs technology for preventing from the extinction. One of the mass propagation is through the technique culture in vitro. This research aimed to get the precise medium and BAP concentration for Kokoleceran, and knowing the response of Kokoleceran growth in in vitro. This research was done in November 2015 until March 2016 at the Laboratory of Biotechnology, Department of Agroecotechnology, Faculty of Agriculture, University of Sultan Ageng Tirtayasa, Serang, Banten. This research used Completely Randomized Design (CRD) two factors. The first factor was medium that were MS and WPM media. The second factor was BAP concentration which consisted of four levels namely $0 \mathrm{mg} \mathrm{L}^{-}$ ${ }^{1}, 1 \mathrm{mg} \mathrm{L}^{-1}, 2 \mathrm{mg} \mathrm{L}^{-1}$, and $3 \mathrm{mg} \mathrm{L}^{-1}$. The results showed that the use of different media and BAP
\end{abstract}


concentrations had no impact on the time appear of shoot, shoot number, and root number. There was effect from both treatments on medium color, and growing of callus on the explants.

Key words : BAP (Benzyl Amino Purine), endemic, kokoleceran (Vatica bantamensis), medium

\section{PENDAHULUAN}

Provinsi Banten memiliki keanekaragaman hayati berupa flora dan fauna yang sebagian diantaranya bersifat endemik. Keanekaragaman tersebut memiliki potensi yang tinggi namun belum dapat termanfaatkan dengan maksimal, bahkan kondisinya semakin mengalami tekanan sebagai akibat dari pencurian plasma nutfah, penyelundupan satwa, perambahan hutan dan kebun, perburuan liar, dan perdagangan flora/fauna yang dilindungi (DISHUTBUN Propinsi Banten, 2012).

Melihat potensi yang dimiliki dari keanekaragaman hayatinya berupa flora, Provinsi Banten memiliki berbagai macam flora khas, salah satunya yaitu tanaman kokoleceran (Vatica bantamensis). Menurut Whitten et al. (1996), tanaman kokoleceran merupakan tanaman endemik Banten yang hanya berada di Semenanjung Ujung Kulon dan berdasarkan Keputusan Menteri Dalam Negeri Nomor 522.53-958 Tahun 2010 tentang penetapan flora dan fauna identitas daerah provinsi, dimana kokoleceran ditetapkan sebagai flora khas yang menjadi identitas/maskot Provinsi Banten (BLHD, 2014).

Menurut International Union for Conservation of Nature (IUCN) pada tahun 1998, saat ini kokoleceran ditetapkan sebagai tanaman yang terancam punah. Habitat dan ekologinya berada di hutan hujan tropis. Tanaman tersebut belum tersebar luas dan diketahui masyarakat secara umum, sehingga pemanfaatannya masih sangat minim. Padahal jika melihat genus yang sama seperti resak hiru (Vatica rassak), kayu tanaman tersebut dapat digunakan sebagai bahan bangunan dan bahan pembuat kapal.

Berdasarkan data dari IUCN, sejak tahun 1998 belum ada penelitian lebih lanjut terhadap tanaman kokoleceran. Melihat kondisinya yang terancam punah, maka perlu adanya upaya pembudidayaan untuk mencegah kepunahan. Menurut Ashton (1996) sampai saat ini teknik budidaya tanaman kokoleceran yang diketahui hanya dengan budidaya yang dilakukan secara generatif yaitu menggunakan biji, sedangkan budidaya menggunakan biji memerlukan waktu yang cukup lama. Sehingga teknik budidaya yang paling memungkinkan dilakukan yaitu perbanyakan secara in vitro.

Perbanyakan secara in vitro adalah suatu metode untuk mengisolasikan bagian dari tanaman seperti protoplas, sel, jaringan, dan organ, serta menumbuhkannya dalam kondisi aseptik. Sehingga bagian-bagian tersebut dapat memperbanyak diri dan beregenerasi menjadi tanaman lengkap kembali (Sandra, 2013).

Menurut Dixon dan Gonzales (2003) dalam Kusumawati et al. (2015), keberhasilan teknologi kultur in vitro dipengaruhi oleh beberapa faktor, diantaranya adalah penggunan bahan tanam (sumber eksplan), ketepatan penggunaan media kultur dan penambahan zat pengatur tumbuh. Sumber eksplan menjadi syarat utama keberhasilan inisiasi. Menurut Uzun et al. (2014), bagian 
tanaman yang dapat dijadikan sumber eksplan adalah pucuk muda, batang muda, daun muda, kotiledon, dan hipokotil.

Selanjutnya media kultur juga dapat menjadi penyebab tumbuh atau tidaknya suatu tanaman. Untuk mendapatkan pertumbuhan tanaman yang optimal dalam kultur jaringan, maka diperlukan media dengan komponen yang tepat. Media dasar yang diperuntukkan khusus tanaman berkayu yaitu media dasar Woody Plant Medium (WPM). Sedangkan menurut Kusumawati et al. (2015), ada media lain yang sering digunakan untuk perbanyakan sejumlah besar spesies tanaman yaitu Media Murashige dan Skoog (MS).

Zat pengatur tumbuh juga memegang peran yang penting dalam pertumbuhan dan perkembangan tanaman. Menurut Yuwono (2012), zat pengatur tumbuh dapat mendukung pertumbuhan suatu tanaman. Imelda et al. (2008) menyatakan bahwa sitokinin dan auksin merupakan zat pengatur tumbuh yang banyak digunakan dalam kultur in vitro. Selanjutnya Mulyono (2010) menambahkan, auksin berfungsi untuk merangsang pembentukan akar sedangkan sitokinin berfungsi untuk merangsang tumbuhnya tunas-tunas aksilar.

Penggunaan sitokinin pada media kultur diharapkan dapat mengatasi masalah rendahnya laju pembelahan sel pada tunas tanaman. BAP (Benzyl Amino Purine) merupakan golongan sitokinin sintetik yang banyak digunakan dalam perbanyakan tanaman secara in vitro. Hal ini karena BAP mempunyai efektifitas yang cukup tinggi untuk perbanyakan tunas, mudah didapat dan relatif murah dibandingkan dengan golongan sitokinin lainnya (Yusnita, 2003).

Berdasarkan uraian diatas, maka perlu dilakukan penelitian yang berjudul inisiasi tunas kokoleceran pada berbagai jenis media tanam dan konsentrasi BAP secara in vitro yang bertujuan untuk mendapatkan media tanam dan konsentrasi BAP yang sesuai untuk pertumbuhan tanaman kokoleceran secara in vitro.

Penelitian ini bertujuan untuk mendapatkan media tanam dan konsentrasi BAP yang sesuai untuk pertumbuhan tanaman kokoleceran secara in vitro, dan mengetahui respon pertumbuhan tunas kokoleceran pada berbagai jenis media tanam dan konsentrasi BAP secara in vitro.

\section{METODE PENELITIAN}

Penelitian ini dilaksanakan pada bulan November 2015 sampai Maret 2016 di Laboratorium Bioteknologi Jurusan Agroekoteknologi Fakultas Pertanian Universitas Sultan Ageng Tirtayasa Serang Banten.

Alat-alat yang digunakan dalam penelitian ini adalah autoklaf, timbangan analitik, laminar air flow cabinet (LAFC), $\mathrm{pH}$ meter, botol kultur, hot plate dan magnetic stirrer, hand sprayer, gelas ukur, gelas piala, erlenmeyer, pipet, skalpel, pinset, bunsen, cawan petri, shaker, timer, kompor, panci, pengaduk, lampu spiritus, corong, rak kultur yang dilengkapi dengan lampu neon sebagai sumber penyinaran, dan alat tulis.

Adapun bahan-bahan yang digunakan adalah eksplan yang berasal dari tunas tanaman kokoleceran, zat kimia penyusun media MS dan media WPM, zat pengatur tumbuh BAP dan IBA (Indole Butyric Acid), PVP (Polivynilpirrolidone), PPM (Plant Preservative Mixture), $\mathrm{HCl} 1 \mathrm{~N}, \mathrm{NaOH} 1 \mathrm{~N}$, air destilasi, alkohol 70\%, alkohol 96\%, natrium hipoklorit $10 \%$, natrium hipoklorit $15 \%$, tween, fungisida, bakterisida, antibiotik, deterjen, sukrosa, air destilasi, 
bubuk agar-agar, kertas label, tisu, aluminium foil, dan plastik gulung.

Rancangan perlakuan yang digunakan adalah Rancangan Acak Lengkap (RAL) yang terdiri dari 2 faktor dengan 3 ulangan.

1) Faktor pertama adalah media tanam dengan 2 taraf konsentrasi yaitu:

$\mathrm{A} 1$ = Media MS

A2 = Media WPM

2) Sedangkan faktor kedua adalah zat pengatur tumbuh BAP dengan 4 taraf konsentrasi yaitu:

$\mathrm{B} 1=\mathrm{BAP} 0 \mathrm{mg} \mathrm{L}^{-1}$

$\mathrm{B} 2=\mathrm{BAP} 1 \mathrm{mg} \mathrm{L}^{-1}$

$\mathrm{B} 3=\mathrm{BAP} 2 \mathrm{mg} \mathrm{L}^{-1}$

$\mathrm{B} 4=\mathrm{BAP} 3 \mathrm{mg} \mathrm{L}^{-1}$

Percobaan terdiri dari 8 kombinasi perlakuan, tiap kombinasi perlakuan terdiri dari 3 ulangan, sehingga jumlah satuan unit percobaan adalah 24 satuan percobaan. Semua perlakuan diberi zat pengatur tumbuh IBA sebanyak $0,5 \mathrm{mg} \mathrm{L}^{-1}$ untuk merangsang pertumbuhan akar.

Metode linier untuk rancangan ini adalah :

$$
Y i j k=\mu+\alpha i+\beta j+(\alpha \beta) i j+\sum i j k
$$

Dimana :

Yijk : Nilai pengamatan pada perlakuan media ke-i, konsentrasi BAP ke-j dan ulangan ke-k

$\mu \quad$ : Nilai tengah umum

ai : Pengaruh perlakuan media ke-i

$\beta j \quad$ : Pengaruh konsentrasi BAP ke-j

$(\alpha \beta)$ ij : Pengaruh interaksi media ke-i dan konsentrasi BAP ke-j

$\sum i j k \quad$ : Pengaruh galat perlakuan media ke-i, konsentrasi BAP ke-j dan pada ulangan ke-k

i $\quad: 1,2$ (Taraf media)

j $\quad: 1,2,3,4$ ( Taraf konsentrasi BAP)

$\mathrm{k}$ : ulangan $1,2,3$

bila hasil sidik ragam menunjukan pengaruh nyata maka dilakukan uji lanjut dengan uji
DMRT ( Duncan Multiple Range Test ) taraf $5 \%$.

\section{Tahapan Kegiatan}

\section{Sterilisasi Alat dan Air}

Peralatan berupa botol kultur, pinset, scalpel, cawan petri, gelas ukur, erlenmeyer dan peralatan gelas lainnya disterilkan dengan cara dicuci dengan detergen kemudian direndam ke dalam larutan klorox selama 24 jam dan kemudian di panaskan menggunakan autoklaf pada temperatur $121^{\circ} \mathrm{C}$ dengan tekanan 17,5 psi (pounds per square inch) selama 15 menit. Setelah tahapan sterilisasi, alat-alat seperti cawan petri, pinset dan scalpel disimpan di dalam oven dengan suhu $80^{\circ} \mathrm{C}$ sampai alat tersebut digunakan. Sedangkan untuk sterilisasi air, air di sterilisasi dengan menggunakan autoklaf pada temperatur $121^{\circ} \mathrm{C}$ dengan tekanan 17,5 psi selama 30 menit.

\section{Pembuatan Media Pra Kondisi}

Air steril $\pm 500 \mathrm{ml}$ dimasukkan ke dalam erlenmeyer kapasitas 1000 ml, kemudian ditambahkan sukrosa sebanyak $30 \mathrm{~g} \mathrm{~L}^{-1}$. Air steril ditambahkan kembali hingga larutan mencapai $1000 \mathrm{ml}$. Kemudian diberikan bubuk agar-agar sebanyak $7 \mathrm{~g} \mathrm{~L}^{-1}$. Media dipanaskan hingga mendidih. Selanjutnya dimasukkan ke setiap botol kultur sebanyak $\pm 25 \mathrm{ml}$. Botol kultur yang sudah berisi media ditutup aluminium foil dan direkatkan dengan plastik wrap. Botol kultur disterilisasi di dalam autoklaf pada suhu $121^{\circ} \mathrm{C}$ selama 20 menit pada tekanan 17,5 psi.

\section{Pembuatan Media Perlakuan}

Sebelum pembuatan media langkah awal yang perlu dilakukan adalah pembuatan larutan stok. Pembuatan media dimulai dengan mengambil larutan stok media MS atau WPM sesuai dengan perlakuan, air steril $\pm 500 \mathrm{ml}$ dimasukkan ke dalam 
erlenmeyer kapasitas 1000 ml, masingmasing larutan stok tersebut diambil sesuai konsentrasi yang ditetapkan. Sukrosa ditambahkan sebanyak $30 \mathrm{~g} \mathrm{~L}^{-1}$ ke dalam larutan, lalu larutan diaduk hingga menjadi homogen. Selanjutnya ditambahkan zat pengatur tumbuh IBA sebanyak $0,5 \mathrm{mg} \mathrm{L}^{-1}$, PVP sebanyak 0,5 $\mathrm{mg} \mathrm{L}^{-1}$, PPM sebanyak 0,5 $\mathrm{mg} \mathrm{L}^{-1}$ dan zat pengatur tumbuh BAP sesuai dengan perlakuan yang dicobakan. Air steril ditambahkan kembali hingga larutan mencapai $980 \mathrm{ml}$ dengan kondisi sedang diaduk. Setelah itu diatur pH hingga 5,7-5,8 dengan $\mathrm{pH}$ meter. Apabila larutan belum menunjukkan nilai $\mathrm{pH}$ tersebut, dilakukan penambahan beberapa tetes $\mathrm{NaOH} 1 \mathrm{~N}$ untuk menaikkan $\mathrm{pH}$ atau $\mathrm{HCl} 1 \mathrm{~N}$ untuk menurunkan $\mathrm{pH}$. Selanjutnya ditambahkan kembali air steril hingga 1000 ml. Kemudian diberikan bubuk agar sebanyak $7 \mathrm{~g} \mathrm{~L}^{-1}$ sebagai bahan pemadat media. Media dipanaskan hingga mendidih. Larutan yang sudah dibuat dimasukkan ke setiap botol kultur sebanyak $\pm 25 \mathrm{ml}$. Botol kultur yang sudah berisi media ditutup aluminium foil dan direkatkan dengan plastik wrap. Botol kultur disterilisasi di dalam autoklaf pada suhu $121^{\circ} \mathrm{C}$ selama 20 menit pada tekanan 17,5 psi.

\section{Sterilisasi Eksplan}

Tunas dicuci di air mengalir sambil dibersihkan menggunakan spons, kemudian direndam dengan larutan deterjen sebanyak $2 \mathrm{~g} \mathrm{~L}^{-1}$ selama 5 menit dan dibilas hingga bersih dengan air steril. Selanjutnya direndam dengan tween selama 10 menit dan dibilas hingga bersih. Kemudian direndam dengan larutan fungisida, bakterisida dan antibiotik sebanyak $2 \mathrm{~g} \mathrm{~L}^{-1}$ dengan penambahan tween \pm 3 tetes, masing-masing direndam selama 1 jam dan dibilas hingga bersih. Sterilisasi berikutnya dilakukan di dalam LAFC dengan meng- gunakan natrium hipoklorit $15 \%$ selama 10 menit dan $10 \%$ selama 15 menit serta alkohol 70\% selama 1 menit, kemudian dibilas hingga bersih.

\section{Penanaman}

Kegiatan penanaman dilakukan di dalam LAFC yang sebelumnya telah dibersihkan dengan alkohol 70\%. Lampu ultraviolet (UV) diaktifkan 30 menit sebelum LAFC digunakan. Alat-alat yang akan dimasukan ke dalam LAFC disemprot dengan alkohol $70 \%$. Alat logam seperti pinset dan scalpel direndam ke dalam alkohol $96 \%$ sebelum digunakan untuk memotong eksplan, lalu dipanaskan di atas bunsen yang menyala. Bagian ujung eksplan dipotong dengan pisau guna memperkecil kemungkinan adanya desinfektan yang terbawa dalam eksplan. Kemudian ditanam ke dalam botol yang telah terisi media pra-kondisi. Setelah penanaman, botol kultur ditutup dengan aluminium foil dan direkatkan dengan plastik wrap. Seluruh kegiatan penanaman dilakukan dekat pembakar bunsen. Setelah 6 hari, eksplan yang tidak terkontaminasi dipindahkan ke dalam media perlakuan.

\section{Pemeliharaan}

Ruang kultur harus selalu dalam keadaan aseptik dan harus dibersihkan setiap hari. Lantai ruangan dipel menggunakan pembersih lantai, sedangkan botol-botol kultur yang berisi tanaman disemprot dengan alkohol $70 \%$ setiap tiga hari. Suhu ruangan diatur pada kisaran $22^{\circ} \mathrm{C}-26^{\circ} \mathrm{C}$. Sumber cahaya yang digunakan berasal dari lampu fluorescent 20 watt yang dipasang pada setiap rak kultur.

\section{Variabel Pengamatan}

\section{Waktu Muncul Tunas (HST)}

Diamati setiap hari untuk mengetahui waktu muncul tunas. 


\section{Jumlah Tunas (Buah)}

Dihitung dengan menjumlahkan tunas yang tumbuh. Dilakukan setiap satu minggu sekali dimulai 1 MST sampai 12 MST.

\section{Jumlah Akar (Buah)}

Dihitung dengan menjumlahkan akar yang tumbuh. Dilakukan setiap satu minggu sekali dimulai 1 MST sampai 12 MST.

\section{Warna Eksplan}

Pengamatan dilakukan pada akhir pengamatan (12 MST) dengan mengamati secara visual. Penentuan warna eksplan ditetapkan berdasarkan scoring :

0 : hijau muda

1 : hijau kecoklatan

2 : cokelat kehijauan

3 : cokelat kekuningan

4 : cokelat kehitaman

\section{Presentase Terbentuknya Kalus (\%)}

Perhitungan dilakukan pada akhir pengamatan (12 MST). Dihitung dengan menggunakan rumus :

\% Terbentuknya Kalus = Jumlah eksplan yang membentuk kalus $\times 100 \%$

$$
\text { Total eksplan }
$$

\section{Presentase Media Browning (\%)}

Perhitungan dilakukan satu minggu sekali dimulai 1 MST sampai 12 MST. Dihitung dengan menggunakan rumus : $\%$ Browning =

Jumlah eksplan yang browning $\times 100 \%$ Total eksplan

\section{Presentase kontaminasi (\%)}

Perhitungan dilakukan satu minggu sekali dimulai 1 MST sampai 12 MST. Dihitung dengan menggunakan rumus : $\%$ Kontaminasi $=$

Jumlah eksplan terkontaminasi $\times 100 \%$ Total eksplan

\section{HASIL DAN PEMBAHASAN}

Tunas yang digunakan berasal dari tanaman kokoleceran yang berada di Pusat Konservasi Tumbuhan Kebun Raya-LIPI asal Semenanjung Ujung Kulon yang berumur \pm 26 tahun. Eksplan ditanam pada media pra-kondisi sebelum ditanam pada media perlakuan. Penggunaan media pra-kondisi terbukti memberikan hasil yang lebih steril. Tingkat browning dan kontaminasi yang terjadi pada media perlakuan dengan prakondisi terlihat lebih rendah dibandingkan dengan media perlakuan tanpa pra-kondisi. Berikut disajikan eksplan pada media prakondisi (Gambar 1).

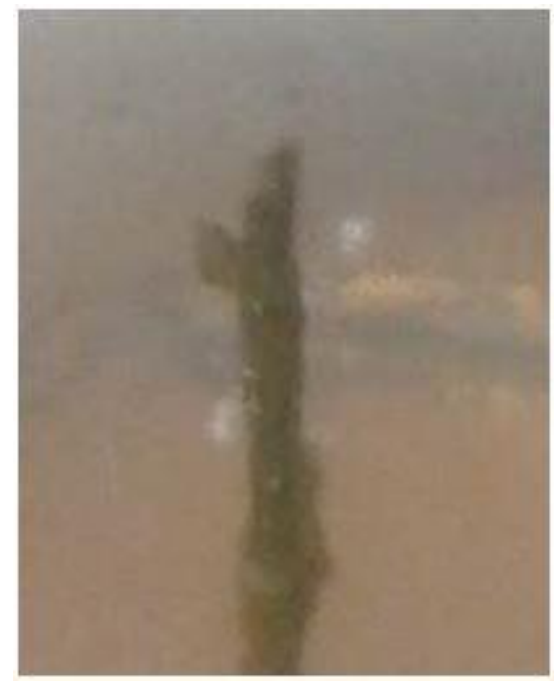

Gambar 1. Eksplan pada Media pra-kondisi

Kontaminasi menjadi kendala utama pada penelitian ini. Odutayo et al. (2007) mengatakan bahwa kontaminasi mikroba merupakan permasalahan yang selalu ada dalam kultur jaringan. Selanjutnya eksplan mengalami stagnasi hingga $12 \mathrm{MST}$, selain dari pertumbuhan tanaman berkayu yang cukup lambat, eksplan juga diduga mengalami dormansi alami, sehingga pertumbuhannya sangat lambat. Tunas muda kokoleceran akan mengalami proses 
penuaan terlebih dahulu, kemudian akan mengalami dormansi yang cukup lama sebelum terjadi pertumbuhan dan menghasilkan tunas baru.

\section{Waktu Muncul Tunas}

Formulasi media tanam dan konsentrasi BAP tidak memberikan pengaruh yang nyata terhadap waktu muncul tunas pada eksplan. Namun pada perlakuan media tanam MS dengan penambahan BAP sebanyak $3 \mathrm{mg} \mathrm{L}^{-1}$ terdapat tonjolantonjolan pada eksplan yang diduga merupakan calon tunas. Seperti yang diungkapkan oleh George dan Sherington (1984) dalam Yunita (2004), bahwa komposisi hara makro yang terkandung pada media MS sangat relevan untuk media awal pertumbuhan eksplan. Berikut disajikan calon tunas pada eksplan (Gambar 2).

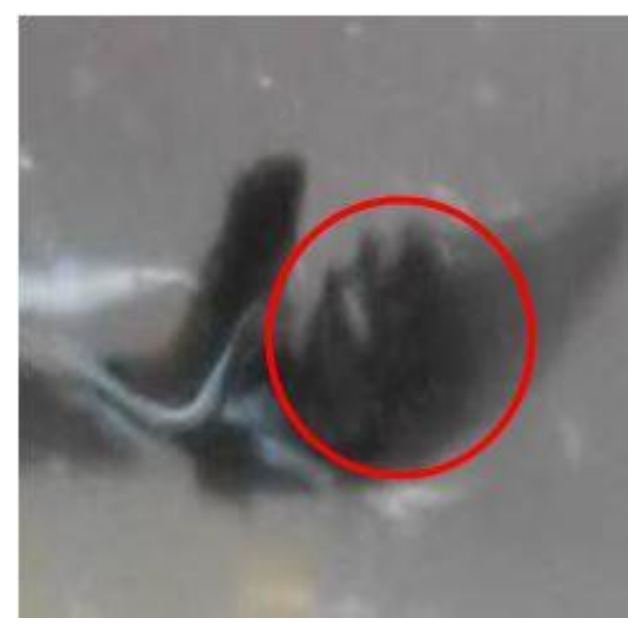

Gambar 2. Bakal Calon Tunas

Tunas yang di kulturkan mengalami kelambatan dalam pertumbuhannya. Hendaryono dan Wijayani (1994) menyatakan, bahwa eksplan yang diambil dari tanaman dewasa (tanaman berkayu) mempunyai kemampuan mengadakan regenerasi yang sangat lemah. Menurut
Cerianingsih et al. (2015) pertumbuhan berbagai bagian tanaman mengalami periode-periode dimana pertumbuhan yang terjadi sangatlah sedikit atau tidak sama sekali yang disebut dengan dormansi.

Bila dilihat dari konsentrasi BAP yang diberikan, BAP belum banyak berperan dalam terbentuknya tunas. Pemberian BAP $1 \mathrm{mg} \mathrm{L}^{-1}$ - $3 \mathrm{mg} \mathrm{L}^{-1}$ membutuhkan waktu yang cukup lama untuk menghasilkan tunas baru. Hal ini menunjukkan bahwa eksplan tidak responsif terhadap zat pengatur tumbuh yang diberikan.

\section{Jumlah Tunas}

Formulasi media tanam dan konsentrasi BAP tidak memberikan pengaruh yang nyata terhadap jumlah tunas pada eksplan. Pemberian BAP baik dalam media MS maupun media WPM, belum mampu menghasilkan jumlah tunas pada eksplan. Dewi (2014) menyatakan bahwa tanaman tahunan memiliki pertumbuhan yang relatif lambat. Menurut Seswita et al. (1996) dalam Lestari (2011), penggandaan tunas pada tanaman berkayu atau tanaman tahunan pada umumnya memerlukan zat pengatur tumbuh sitokinin dalam konsentrasi yang lebih tinggi berkisar antara 5$10 \mathrm{mg} \mathrm{L}^{-1}$, untuk meningkatkan kemampuan proliferasi tunas dan kadang perlu ditambahkan auksin dalam konsentrasi yang rendah $\left(0,1 \mathrm{mg} \mathrm{L}^{-1}-0,3 \mathrm{mg} \mathrm{L}^{-1}\right)$.

\section{Jumlah Akar}

Formulasi media tanam dan konsentrasi BAP tidak memberikan pengaruh yang nyata terhadap jumlah akar pada eksplan. Dengan penambahan IBA 0,5 $\mathrm{mg} \mathrm{L}^{-1}$, eksplan belum mampu menghasilkan akar baik pada media MS maupun media WPM. Menurut Lestari (2011), pada tanaman tertentu terjadi kesulitan dalam pembentukan akar. 
Sehingga dibutuhkan konsentrasi auksin yang tepat untuk dapat memacu pertumbuhan akar.

\section{Warna Eksplan}

Warna eksplan diawali dari warna hijau muda, hijau kecoklatan, cokelat kehijauan, cokelat kekuningan hingga cokelat kehitaman (Gambar 3).

Perubahan warna eksplan menjadi kecokelatan merupakan salah satu indikasi terjadinya pencoklatan (browning) pada eksplan (Tabel 1). Menurut Hutami (2008), pencoklatan sangat umum terjadi pada spesies tanaman berkayu, terutama bila eksplan diambil dari pohon dewasa. Fitriani (2003) dalam Nisa dan Rodinah (2005) mendapatkan bahwa warna coklat pada eksplan menandakan sintesis senyawa fenolik. Pencoklatan ini sering membuat tidak terjadinya pertumbuhan dan perkembangan eksplan.

\section{Presentase Terbentuknya Kalus}

Menurut Lina et al. (2013), kalus merupakan sel-sel yang belum terdiferensiasi, terbentuk di seluruh permukaan irisan eksplan sehingga semakin luas permukaan irisan eksplan, semakin cepat dan banyak kalus yang terbentuk.

Hasil penelitian menunjukkan bahwa presentase eksplan terbentuk kalus sebesar $30 \%$ atau sebanyak 6 eksplan (Tabel 2). Kalus terbentuk pada umur 4 MST dan terdapat pada ujung eksplan yang sebelumnya telah mengalami pelukaan atau bekas irisan. Kalus yang terbentuk bermacam-macam, ada yang berwarna putih, putih kehijauan dan berwarna putih kecokelatan (Gambar 4).
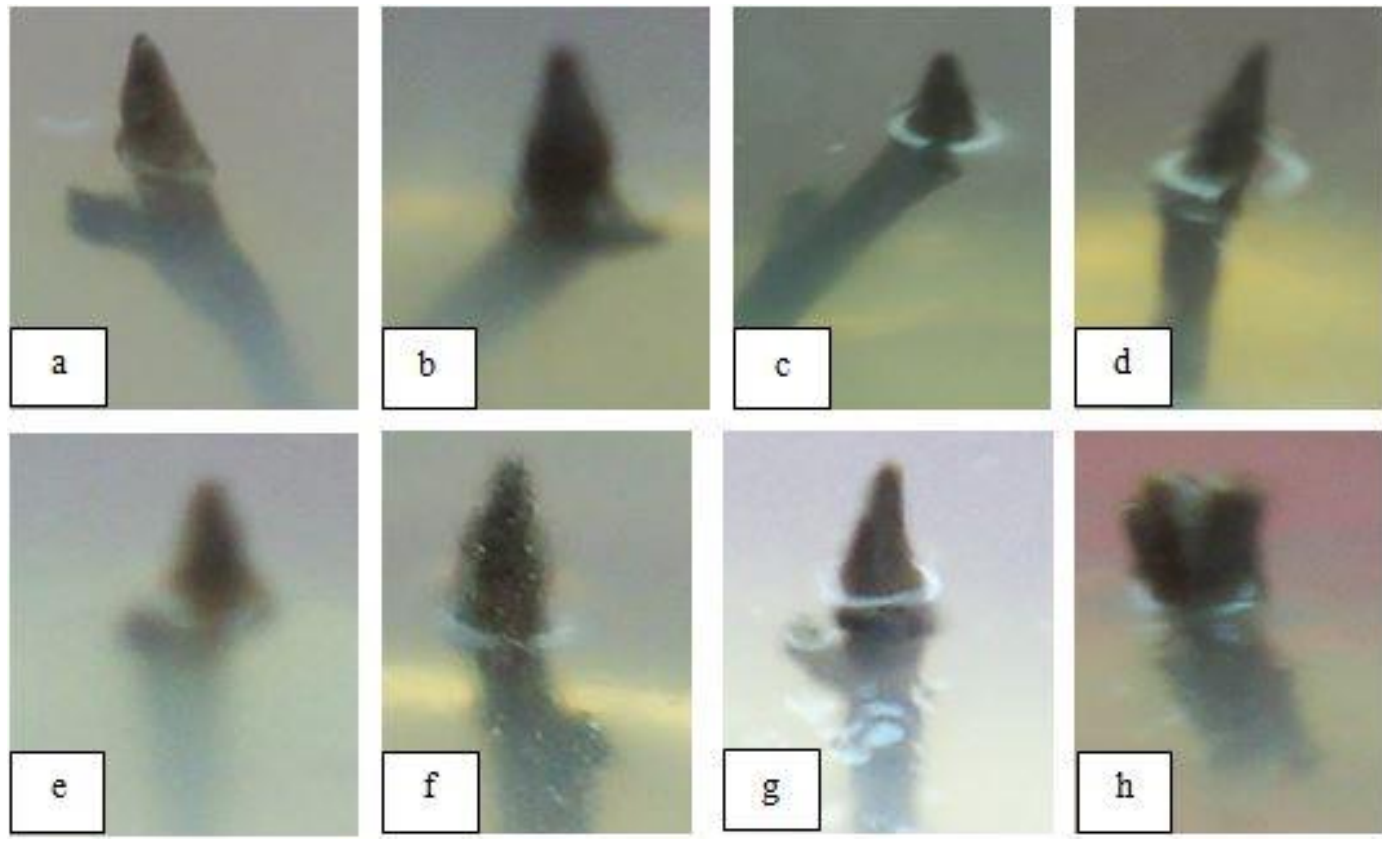

Gambar 3. Penampilan dan warna dari eksplan kokoleceran pada berbagai media perlakuan: (a) A1B1. (b) A1B2. (c) A1B3. (d) A1B4. (e) A2B1. (f) A2B2. (g) A2B3. (h) A2B4. 
Tabel 1. Warna Eskplan Kokoleceran

\begin{tabular}{|c|c|c|c|}
\hline Perlakuan & Jenis Perlakuan & Skoring & Warna Eksplan \\
\hline A1B1 (U1) & & 3 & Cokelat kekuningan \\
\hline A1B1 (U2) & $\mathrm{MS}+\mathrm{BAP} 0 \mathrm{mg} \mathrm{L}^{-1}$ & 4 & Cokelat kehitaman \\
\hline A1B1 (U3) & & 3 & Cokelat kekuningan \\
\hline A1B2 (U1) & & 3 & Cokelat kekuningan \\
\hline A1B2 (U2) & $\mathrm{MS}+\mathrm{BAP} 1 \mathrm{mg} \mathrm{L}^{-1}$ & 3 & Cokelat kekuningan \\
\hline A1B2 (U3) & & 3 & Cokelat kekuningan \\
\hline A1B3 (U1) & & 3 & Cokelat kekuningan \\
\hline A1B3 (U2) & $\mathrm{MS}+\mathrm{BAP} 2 \mathrm{mg} \mathrm{L}^{-1}$ & 3 & Cokelat kekuningan \\
\hline A1B3 (U3) & & 3 & Cokelat kekuningan \\
\hline A1B4 (U1) & & 3 & Cokelat kekuningan \\
\hline A1B4 (U2) & $\mathrm{MS}+\mathrm{BAP} 3 \mathrm{mg} \mathrm{L}^{-1}$ & 3 & Cokelat kekuningan \\
\hline A1B4 (U3) & & 3 & Cokelat kekuningan \\
\hline A2B1 (U1) & & 3 & Cokelat kekuningan \\
\hline A2B1 (U2) & $W P M+B A P 0 g^{-1}$ & 3 & Cokelat kekuningan \\
\hline A2B1 (U3) & & 3 & Cokelat kekuningan \\
\hline A2B2 (U1) & & 4 & Cokelat kehitaman \\
\hline $\mathrm{A} 2 \mathrm{~B} 2$ (U2) & $W P M+B A P 1 \mathrm{mg} \mathrm{L}^{-1}$ & 3 & Cokelat kekuningan \\
\hline A2B2 (U3) & & 3 & Cokelat kekuningan \\
\hline A2B3 (U1) & & 3 & Cokelat kekuningan \\
\hline A2B3 (U2) & $W P M+B A P 2 m g L^{-1}$ & 3 & Cokelat kekuningan \\
\hline A2B3 (U3) & & 3 & Cokelat kekuningan \\
\hline A2B4 (U1) & & 3 & Cokelat kekuningan \\
\hline A2B4 (U2) & $W P M+B A P 3 g^{-1}$ & 3 & Cokelat kekuningan \\
\hline A2B4 (U3) & & 3 & Cokelat kekuningan \\
\hline
\end{tabular}

Keterangan :

$\mathrm{A} 1$ = Media MS

$\mathrm{B} 1=\mathrm{BAP} 0 \mathrm{mg} \mathrm{L}^{-1}$

$\mathrm{B} 3=\mathrm{BAP} 2 \mathrm{mg} \mathrm{L}^{-1}$

A2 = Media WPM

$\mathrm{B} 2=\mathrm{BAP} 1 \mathrm{mg} \mathrm{L}^{-1}$

$\mathrm{B} 4=\mathrm{BAP} 3 \mathrm{mg} \mathrm{L}^{-1}$

Tabel 2. Pengaruh Jenis Media Tanam dan BAP terhadap Presentase Terbentuknya Kalus pada Tanaman Kokoleceran

\begin{tabular}{ccccc}
\hline Perlakuan & Eksplan Awal & Eksplan Akhir & $\begin{array}{c}\text { Eksplan Terbentuk } \\
\text { Kalus }\end{array}$ & $\begin{array}{c}\text { Eksplan Terbentuk } \\
\text { Kalus }\end{array}$ \\
\hline & & ----- & & $--\%--$ \\
A1 B1 & 3 & 2 & 1 & 50 \\
A1 B2 & 3 & 3 & 0 & 0 \\
A1 B3 & 3 & 2 & 1 & 50 \\
A1 B4 & 3 & 3 & 1 & 33,33 \\
A2 B1 & 3 & 3 & 1 & 33,33 \\
A2 B2 & 3 & 3 & 0 & 0 \\
A2 B3 & 3 & 3 & 1 & 33,33 \\
A2 B4 & 3 & 1 & 1 & 100 \\
\hline Total & 24 & 20 & 6 & 30 \\
\hline
\end{tabular}

Keterangan :

$\mathrm{A} 1=$ Media MS

$\mathrm{B} 1=\mathrm{BAP} 0 \mathrm{mg} \mathrm{L}^{-1}$

$\mathrm{B} 3=\mathrm{BAP} 2 \mathrm{mg} \mathrm{L}^{-1}$

$A 2=$ Media WPM

$B 2=B A P 1 \mathrm{mg} \mathrm{L}^{-1}$

$B 4=B A P 3 \mathrm{mg} \mathrm{L}^{-1}$ 
Pembentukan kalus yang terjadi disebabkan karena adanya penambahan zat pengatur tumbuh golongan auksin yaitu IBA sebanyak 0,5 $\mathrm{mg} \mathrm{L} \mathrm{L}^{-1}$ ke dalam media. Menurut George et al. (2008), auksin dapat digunakan untuk induksi kalus pada eksplan. Gunawan (1988) dalam Lidyawati et al. (2012) juga mengemukakan bahwa auksin berperan dalam mendorong pembelahan sel dan pembentukan kalus. Namun pertumbuhan kalus mengalami keterlamba- tan dikarenakan kurangnya auksin yang diberikan.

Terdapat dua tipe kalus yang terlihat pada percobaan ini. Tipe pertama yaitu kalus putih kehijauan yang memiliki ciri-ciri struktur kalusnya kompak dan tumbuh secara berkelompok di salah satu sisi eksplan (kalus kompak). Kalus tipe dua berwarna putih kecoklatan, struktur kalusnya remah dan menyebar di seluruh permukaan eksplan (kalus remah).
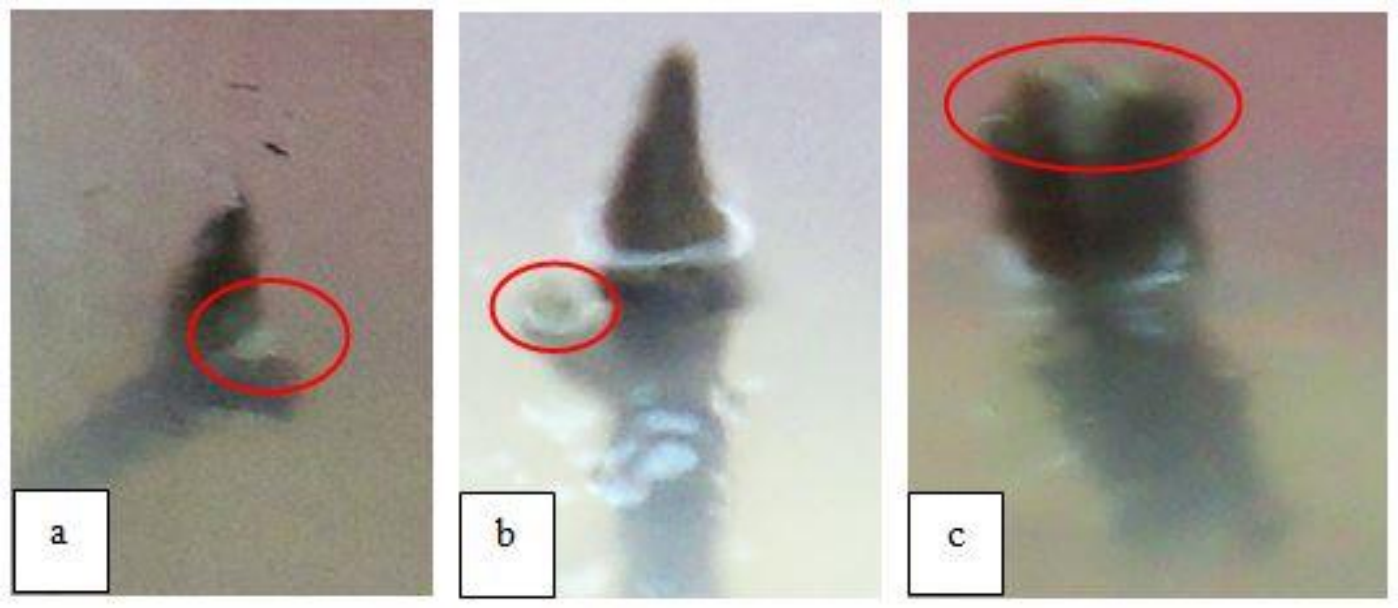

Gambar 4. (a) Kalus berwarna putih. (b) Kalus berwarna putih kehijauan. (c) Kalus berwarna putih kecoklatan.

\section{Presentase Media Browning}

Pencoklatan (browning) pada media merupakan perubahan yang terjadi pada media yang berubah menjadi coklat (browning) setelah penanaman eksplan ke dalam media yang selanjutnya dapat menghambat pertumbuhan dan akhirnya menyebabkan kematian jaringan (Hutami, 2008). Hasil penelitian menunjukkan presentase media browning sebesar $75 \%$ atau sebanyak 14 media (Tabel 3).

Browning terlihat sejak awal penanaman (1 MST) di sekitar eksplan namun memudar setelah 2 MST dan mulai menyebar ke seluruh permukaan eksplan setelah 4 MST. Browning disebabkan karena adanya senyawa fenol dari eksplan yang telah teroksidasi. Menurut Kosmiatin et al. (2005), beberapa macam tanaman khususnya tanaman berkayu mempunyai kandungan senyawa fenol yang tinggi yang teroksidasi ketika sel dilukai sehingga menghambat pertumbuhan eksplan.

Penggunaan media MS dan WPM memberikan pengaruh yang berbeda terhadap warna media. Seluruh media MS mengalami perubahan warna menjadi kecoklatan (Gambar 5). Perubahan warna tersebut disebabkan karena fenol yang berada pada eksplan telah menyebar ke dalam media. 
Tabel 3. Pengaruh Jenis Media Tanam dan Konsentrasi BAP terhadap Presentase Media Browning pada Tanaman Kokoleceran

\begin{tabular}{|c|c|c|c|}
\hline Perlakuan & Media Awal & Media Browning & Media Browning \\
\hline & \multicolumn{2}{|c|}{$--\sum--$} & --\%-- \\
\hline A1 B1 & 3 & 3 & 100 \\
\hline $\mathrm{A} 1 \mathrm{~B} 2$ & 3 & 3 & 100 \\
\hline A1 B3 & 3 & 3 & 100 \\
\hline A1 B4 & 3 & 3 & 100 \\
\hline A2 B1 & 3 & 0 & 0 \\
\hline $\mathrm{A} 2 \mathrm{~B} 2$ & 3 & 3 & 100 \\
\hline $\mathrm{A} 2 \mathrm{~B} 3$ & 3 & 0 & 0 \\
\hline $\mathrm{A} 2 \mathrm{~B} 4$ & 3 & 3 & 100 \\
\hline Total & 24 & 18 & 75 \\
\hline
\end{tabular}

Keterangan :

A1 = Media MS

A2 = Media WPM

$\mathrm{B} 1=\mathrm{BAP} 0 \mathrm{mg} \mathrm{L}^{-1}$

$\mathrm{B} 2=\mathrm{BAP} 1 \mathrm{mg} \mathrm{L}^{-1}$

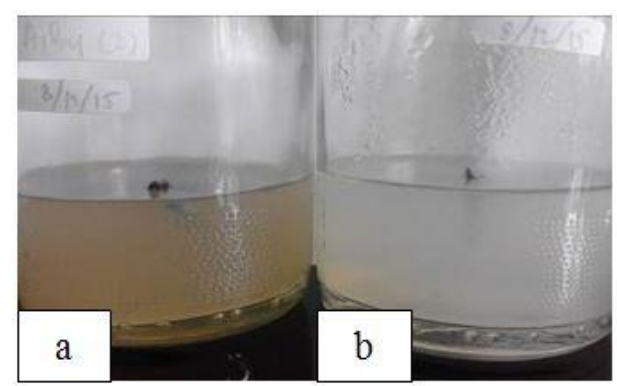

Gambar 5. Perbedaan warna media tanam. (a) Media MS (b) Media WPM

Menurut Fauzi (2010), senyawa fenol umumnya dihasilkan oleh tanaman berkayu dan dikeluarkan ke medium bila jaringan tanaman tersebut ditumbuhkan. Sedangkan pada media WPM hanya sedikit yang mengalami perubahan warna hingga akhir pengamatan. Hal ini dikarenakan tingginya kandungan sulfur yang dimiliki oleh WPM. Menurut Goerge et al. (2008) sulfur memiliki kandungan yang bernama glutation berfungsi sebagai antioksidan sehingga dapat mencegah terjadinya oksidasi.

Bhatt dan Dhar (2004) melaporkan bahwa polivinilpirolidone (PVP) 0,5\% sangat efektif untuk menghilangkan
$\mathrm{B} 3=\mathrm{BAP} 2 \mathrm{mg} \mathrm{L}^{-1}$
$\mathrm{~B} 4=\mathrm{BAP} 3 \mathrm{mg} \mathrm{L}^{-1}$

senyawa fenolat pada mikropropagasi Myrica esculenta. Namun pada penelitian ini PVP yang diberikan belum mampu menanggulangi senyawa fenol secara keseluruhan. Akibatnya eksplan serta media menjadi coklat.

\section{Presentase Kontaminasi}

Kontaminasi merupakan permasalahan yang selalu ada dalam kultur jaringan (Odutayo et al., 2007). Hasil penelitian menunjukkan presentase eksplan terkontaminasi sebesar $16,67 \%$ atau sebanyak 4 eksplan (Tabel 4). Kontaminasi yang terjadi disebabkan karena eksplan yang digunakan dalam penelitian ini diambil dari lapangan, kemungkinan bahan tanam tersebut lebih banyak mengandung berbagai kontaminan yang dapat dijumpai baik pada permukaan maupun dalam jaringan, sehingga kontaminasi mikroba pada eksplan tersebut belum berhasil di eliminasi sepenuhnya. Menurut Bausher dan Niedz (1998) dalam Dewanto (2014), pengontrolan kontaminasi mikroba sangat sulit dilakukan terutama untuk tanaman berkayu yang berasal dari lapangan. 
Tabel 4. Pengaruh Jenis Media Tanam dan Konsentrasi BAP terhadap Presentase Kontaminasi pada Tanaman Kokoleceran

\begin{tabular}{ccccc}
\hline Perlakuan & $\begin{array}{c}\text { Eksplan } \\
\text { Awal }\end{array}$ & $\begin{array}{c}\text { Eksplan } \\
\text { Terkontaminasi }\end{array}$ & $\begin{array}{c}\text { Eksplan } \\
\text { Terkontaminasi }\end{array}$ & Keterangan \\
\hline A1 B1 & 3 & $--\sum--$ & $--\%--$ & Jamur \\
A1 B2 & 3 & 0 & 33,33 & Bakteri + jamur \\
A1 B3 & 3 & 1 & 0 & \\
A1 B4 & 3 & 0 & 33,33 & \\
A2 B1 & 3 & 0 & 0 & Jamur \\
A2 B2 & 3 & 0 & 0 & \\
A2 B3 & 3 & 0 & 0 & \\
A2 B4 & 3 & 2 & 0 & \\
\hline Total & 24 & 4 & 16,67 & \\
\hline
\end{tabular}

Keterangan :

$\mathrm{A} 1$ = Media MS

A2 = Media WPM

$\mathrm{B} 1=\mathrm{BAP} 0 \mathrm{mg} \mathrm{L}^{-1}$
$\mathrm{~B} 2=\mathrm{BAP} 1 \mathrm{mg} \mathrm{L}^{-1}$

Kontaminasi yang disebabkan oleh jamur ditandai dengan munculnya hifa yang berupa benang-benang halus yang berwarna putih, sedangkan kontaminasi yang disebabkan oleh bakteri ditandai dengan munculnya lendir-lendir yang berwarna kekuningan. Jamur merupakan sumber kotaminan terbanyak dalam penelitian ini.

\section{SIMPULAN DAN SARAN}

\section{Simpulan}

1. Penggunaan media tanam baik media MS maupun media WPM belum mampu menunjukkan hasil yang terbaik bagi pertumbuhan eksplan pada semua parameter.

2. Pemberian zat pengatur tumbuh BAP dengan konsentrasi 0,1 , 2, dan $3 \mathrm{mg} / \mathrm{l}$ dengan penambahan IBA $0,5 \mathrm{mg} / \mathrm{l}$ belum dapat memacu pertumbuhan tunas dan akar eksplan pada semua parameter. Namun memacu
$\mathrm{B} 3=\mathrm{BAP} 2 \mathrm{mg} \mathrm{L}^{-1}$

$\mathrm{B} 4=\mathrm{BAP} 3 \mathrm{mg} \mathrm{L}^{-1}$

pertumbuhan kalus pada beberapa perlakuan.

3. Tidak terdapat interaksi antara media tanam dengan zat pengatur tumbuh yang diberikan pada pertumbuhan eksplan.

\section{Saran}

1. Pengambilan bahan tanam (eksplan) kokoleceran sebaiknya dilakukan pada musim kemarau.

2. Perlu dicari kondisi terbaik bagi pertumbuhan tunas dan akar eksplan kokoleceran, antara lain penggunaan jenis, konsentrasi serta keseimbangan zat pengatur tumbuh yang tepat untuk memperoleh hasil yang optimal.

3. Perlu penelitian lanjutan dengan menggunakan berbagai jenis eksplan mengingat pertumbuhan kokoleceran dari eksplan tunas pucuk sangat lambat, sehingga membutuhkan waktu yang relatif lama untuk menumbuhkan tunas kokoleceran. 


\section{DAFTAR PUSTAKA}

Ashton, P.S. 1996. Vatica bantamensis In: Plants Yielding Non-Seed Carbohydrates. Prosea. 9 p.364.

1998. Vatica bantamensis. The IUCN Red List of Threatened Species. Version 2015.1. www.iucnredlist.org. [11 September 2015].

Bhatt, I.D. and U. Dhar. 2004. Factor controlling micropropagation of Myrica esculenta buch.-Ham. ex. D. Don: A High Value Wild Edible of Kumun Himalaya. African J. Biotechnology. 3 (10) : 534540.

BLHD. 2014. Blhd.bantenprov.go.id.. Konservasi dan Rehabilitasi Kerusakan SDA. http://Blhd.bantenprov.go.id/ [2 November 2015].

Cerianingsih, M.W., I.A. Astarini, dan I.G.M.O. Nurjaya. 2015. Pengaruh Kombinasi Zat Pengatur Tumbuh Indole3-Butyric Acid (IBA) Dan 6-Benzil Amino Purin (BAP) Pada Kultur In Vitro Tunas Aksilar Anggur (Vitis vinifera L.) Varietas Prabu Bestari Dan Jestro Ag 86. J. Metamorfosa. Journal of Biological Sciences. II (1) : 1-8.

Dewanto, M.W. 2014. Pengaruh Zat Pengatur Tumbuh BAP dan NAA Terhadap Pertumbuhan Tunas Ulin (Eusideroxylon zwageri T. et B.) secara in Vitro. Skripsi. Institut Pertanian Bogor. Bogor.

Dewi, P.S. 2014. Multiplikasi Tunas Tanaman Gaharu (Aquilaria filaria) Pada Media WPM dengan Penambahan Konsentrasi Kinetin dan NAA (Naphtalene Acetic Acid) secara in Vitro. Skripsi. Universitas Sultan Ageng Tirtayasa. Banten.

DISHUTBUN Propinsi Banten. 2012. [11 September 2015].

Dishutbun.bantenprov.go.id
Fauzi, A.R. 2010. Induksi Multiplikasi Tunas Ubi Kayu (Mannihot esculenta Crantz.) var. Adira 2 secara in Vitro. Skripsi. Institut Pertaian Bogor. Bogor.

George, E.F., M.A. Hall, dan G.J.D. Klerk. 2008. Plant Propagation by Tissue Culture $3^{\text {rd }}$ Edition. Springer. Netherlands.

Hendaryono D.P.S., dan A. Wijayani. 1994. Teknik Kultur Jaringan, Pengenalan dan Petunjuk Perbanyakan Secara Vegetatif. Kanisius. Yogyakarta.

Hutami, S. 2008. Masalah Pencoklatan pada Kultur Jaringan. J. AgroBiogen $4(2): 83-88$.

Imelda, M., A. Wulansari., dan Y.S. Poerba. 2008. Regenerasi Tunas dari Kultur Tangkai Daun Iles-iles (Amorphophallus muelleri Blume). J. Biodiversitas. 9(3) : 173-176

IUCN. 1998. Guidelines for ReIntroduction. Prepared by IUCN / SSC Re-introduction Specialist Group. IUCN, Gland, Swizerlland and Cambridge, UK, 10 pp.Kosmiatin, M., A. Husni, dan I. Mariska. 2005. Perkecambahan dan Perbanyakan Gaharu secara in Vitro. J. AgroBiogen. 1(2):62-67

Kusumawati, E., Y.P. Sari, dan T. Purnaningsih. 2015. Pengaruh NAA dan BAP Terhadap Inisiasi Tunas Mengkudu (Morinda citrifolia) secara in Vitro. J. Budidaya Tanaman Perkebunan. 1 (1)

Lestari, E.G. 2011. Peranan Zat Pengatur Tumbuh dalam Perbanyakan Tanaman melalui Kultur Jaringan. J. AgroBiogen $7(1): 63-68$

Lidyawati, N. N., Waeniati, Muslimin, dan I.N. Suwastika. 2012. Perbanyakan Tanaman Melon (Cucumis melo L.) secara in Vitro Pada Medium MS dengan Penambahan Indole Acetic Acid (IAA) dan Benzil Amino Purin (BAP). J. Natural Science . 1 (1) : 43-52 
Lina, F.R., E. Ratnasari, dan R. Wahyono. 2013. Pengaruh 6-benzylamino purine (BAP) dan 6-furfuryl amino purine (Kinetin) pada Media MS Terhadap Pertumbuhan Eksplan Ujung Apikal Tanaman Jati secara in Vitro. J. LenteraBio. 2 (1) 57-61

Mulyono, D. 2010. Pengaruh Zat Pengatur Tumbuh Auksin: Indole Butiric Acid (IBA) dan Sitokinin: Benzil Amino Purine (BAP) dan Kinetin dalam Elongasi Pertunasan Gaharu (Aquilaria beccariana). J. Sains dan Teknologi Indonesia. 12 (1)

Nisa, C., dan Rodinah. 2005. Kultur Jaringan Beberapa Kultivar Buah Pisang (Musa paradisiaca L.) dengan Pemberian Campuran NAA dan Kinetin. J. Bioscientiae. 2 (2) : 23-36

Odutayo, O.I., N.A. Amusa, O. O. Okutade, and Y.R. Ogunsanwo. 2007. Determination of the Source of Microbial Contaminants of Cultured Plant Tissues. Plant Pathology Journal. 6 (1) : 77-81
Sandra, E. 2013. Cara Mudah Memahami dan Menguasai Kultur Jaringan. IPB Press. Bogor.

Uzun S, Ilbas Al, Ipek A, Arslan N, Barpete S. 2014. Efficient in Vitro Plant Regeneration From Immature Embryos of Endemic Iris sari and I. schachtii. J. Agric. For. 38: 348-353.

Whitten, T., R.E. Soeriaatmadja, S.A. Afiff. 1996. The Ecology of Indonesia Series Volume II : The Ecology of Java and Bali. Periplus Editions (Hk) Ltd.

Yunita, R. 2004. Multiplikasi Tunas Melinjo (Gnetum gnemon) secara in Vitro. J. Sagu 3(1) :1-8.

Yusnita. 2003. Kultur Jaringan: Cara Memperbanyak Tanaman secara Efisien. Agromedia Pustaka. Jakarta.

Yuwono, T. 2012. Bioteknologi Pertanian. Gadjah Mada University Press. Yogyakarta. 